\title{
Investigation of the Effect of using Salak Seeds as Coarse Aggregate in Concrete
}

\author{
Andi Sulfanita ${ }^{1}$, Gufran Darma Dirawan ${ }^{2}$, Muhammad Ichsan Ali $^{3}$ \\ ${ }^{1}$ Universitas Muhammadiyah \\ Pare-Pare, South Sulawesi, Indonesia \\ Email: andisulfanita [AT] gmail.com \\ ${ }^{2}$ Universitas Negeri Makassar \\ Makassar, South Sulawesi, Indonesia \\ Email: gufrandarma [AT] unm.ac.id \\ ${ }^{3}$ Universitas Negeri Makassar \\ Makassar, South Sulawesi, Indonesia \\ Email: m.ichsan.ali [AT] unm.ac.id
}

\begin{abstract}
This study described the effect of using salak seed waste as a substitute for coarse aggregate. The percentage of salak seed in concrete mixture became experimental variable to discover the best compressive strength of concrete.

Quantitative study with experimental study was carried out at the Laboratory of Materials and Concrete, Faculty of Engineering, University. The design of experiment used a designed compressive strength of concrete of $20 \mathrm{Mpa}$. The experiment consisted of five variations in the percentage of salak seeds, namely $0 \%, 5 \%, 10 \%, 15 \%$, and $20 \%$. The slump test is carried out immediately after mixing the concrete in each proportion. Furthermore, 20 pieces of cylindrical concrete samples in each treatment were tested for 7,14,21 and 28 days. This method aims to compare the strength of each of the resulting concrete compositions. The results obtained showed that the use of salak seeds with a percentage of 5\% and $10 \%$ gave a compressive strength value of 28 days which met the standard compressive strength of the design female. Meanwhile, the percentage of salak seeds $15 \%$ and $20 \%$ did not produce the planned compressive strength value. Therefore, salak seeds are suitable to be used as a substitute for coarse aggregate with a percentage of less than 10\%. The higher the substitution of the mixture in the salak seed concrete, the lower the compressive strength of the concrete. The results of this study can be developed in green concrete studies that use waste.
\end{abstract}

Keywords--- Compressive strength, mixture proportion, waste

\section{INTRODUCTION}

Natural aggregate as a basic material for concrete is widely used in Indonesia. The potential of river materials spread throughout Indonesia makes it easier for people to exploit these materials as concrete materials. However, the exploitation activities are excessive and cause environmental degradation [1]. With these considerations, the idea of using waste to reduce the use of coarse aggregate is also growing. The problem of increasing organic waste is also considered to cause a decrease in environmental quality

Problems of increasing organic waste can be overcome by by utilizing it for construction purposes or the manufacture of other materials [2], [3]. In terms of construction, especially in the manufacture of concrete, there have been a lot of use of organic waste in concrete mixtures, both as replacement materials and as partial substitutes for materials in concrete mixtures, besides being an innovation in concrete mixtures, it also contributes to reducing organic waste [4]-[6]

The use of organic waste in mixing concrete is an innovation for the discovery of new materials in the manufacture of concrete and has been proven to be used for construction work. Organic waste as a concrete material has been proven to produce concrete characteristics that qualify national and international standards.

Utilization of organic waste has been widely studied for many purposes. Utilization of palm shells as a substitute for coarse aggregate aims to reduce the cost of producing concrete. In addition, the use of 5\% palm kernel shells as a substitute for coarse aggregate results in satisfactory workability and compressive strength of concrete [7]. Furthermore, a description of the use of various agricultural wastes such as bamboo, corn, bananas, wheat, olives, elephant grass, or dates as an additive to concrete is not only an application of green concrete. The use of agricultural waste as a partial replacement of aggregates also contributes to the reduction of natural resource exploration in the construction industry [8].

One type of agricultural waste that is commonly found in Indonesia is salak seeds. Salak (Salacca edulis) is a fruit 
whose skin is scaly and brown in color and can be found in almost all parts of Indonesia. The fibrous flesh of the salak fruit is very popular with the community. In one salak fruit there are 1-3 seeds. Salak seeds are hard with sizes varying between $0.8 \mathrm{~cm}-1.2 \mathrm{~cm}$. The fruit consumptions in seed yield residual bark and immediately discarded because they are not useful.

This study introduces the use of seed bark (Salak seeds) as a substitute for coarse aggregate in the concrete mix. The use of salak fruit seeds in several articles is as a biofilm bed to release the sulfide content in the liquid. However, its use as a concrete material is a new innovation and has never been studied before. The availability of this material is spread throughout Indonesia and is easy to find throughout the year.

\section{MATERIALS AND METHODS}

This study is a quantitative research with experimental testing through the Design of Experiment approach [9],[10] The study was conducted in Concrete Laboratory, Faculty of Engineering, University of Muhammadiyah Pare Pare by using materials and waste bark seed instead of coarse aggregate. The procedure for making a concrete mix plan is based on the standard for making concrete in Indonesia ( SK.SNI.T-15-1990-03) with a design compressive strength of 20 $\mathrm{MPa}$. The composition of the constituent materials for $1 \mathrm{~m} 3$ of concrete is presented in table 1

Table 1. Results of mix design

\begin{tabular}{|l|l|}
\hline Material & Weight \\
\hline Water & $190 \mathrm{~kg}$ \\
\hline Cement Portland & $542,86 \mathrm{~kg}$ \\
\hline Fine aggregate & $644,73 \mathrm{~kg}$ \\
\hline Coarse aggregate & $845,41 \mathrm{~kg}$ \\
\hline
\end{tabular}

The use of salak seeds as a substitute material with variations in the composition of $0 \%, 5 \%, 10 \%, 15 \%$ and $20 \%$ of the total coarse aggregate. The size of seeds is presented on figure 1

The sources of concrete constituent materials are presented in the following table:

Table 2. Material and Sources

\begin{tabular}{|c|c|}
\hline Materials & Material Sources \\
\hline Cement & The cement used is in accordance with SNI 15-7064-2004 standard with \\
$50 \mathrm{~kg}$ bag packaging \\
\hline Water & PDAM \\
\hline Fine Aggregate & Bili-bili (Kabupaten Gowa) \\
\hline Coarse Aggregate & Jeneberang River (Gowa) \\
\hline Salak seeds & Organic waste \\
\hline
\end{tabular}




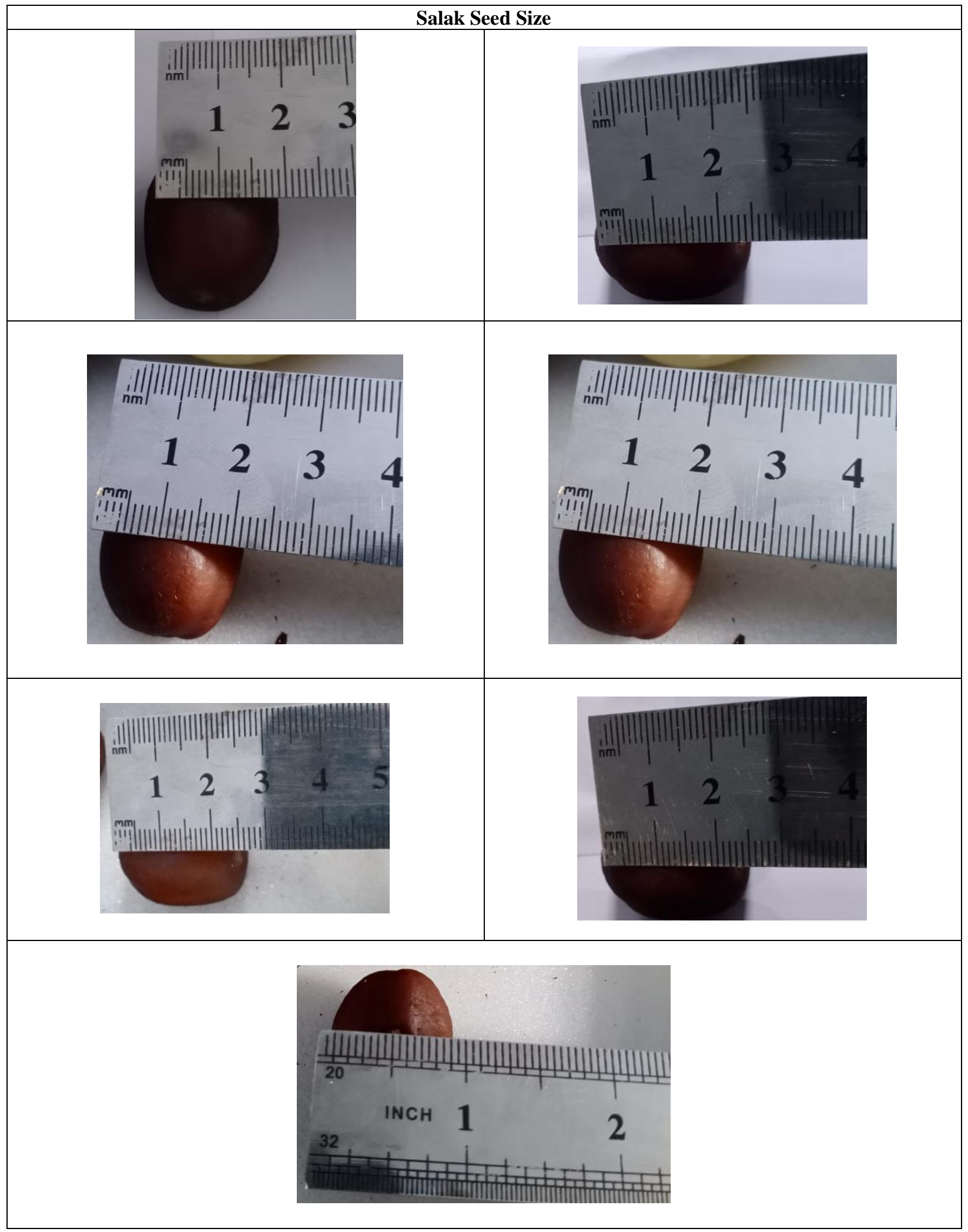

Fig. 1. Salak Seeds Size

Parameters of fine aggregate and coarse aggregate refers to SNI-03-2461-1991/2002; SII.0052.80;ASTM C33). Furthermore, workability check uses slump test while the compressive strength testing uses a comprehensive strenght on the concrete ages 3, 7, 14, 21 and 28 days. The experimental test stages are presented in Figure 2 


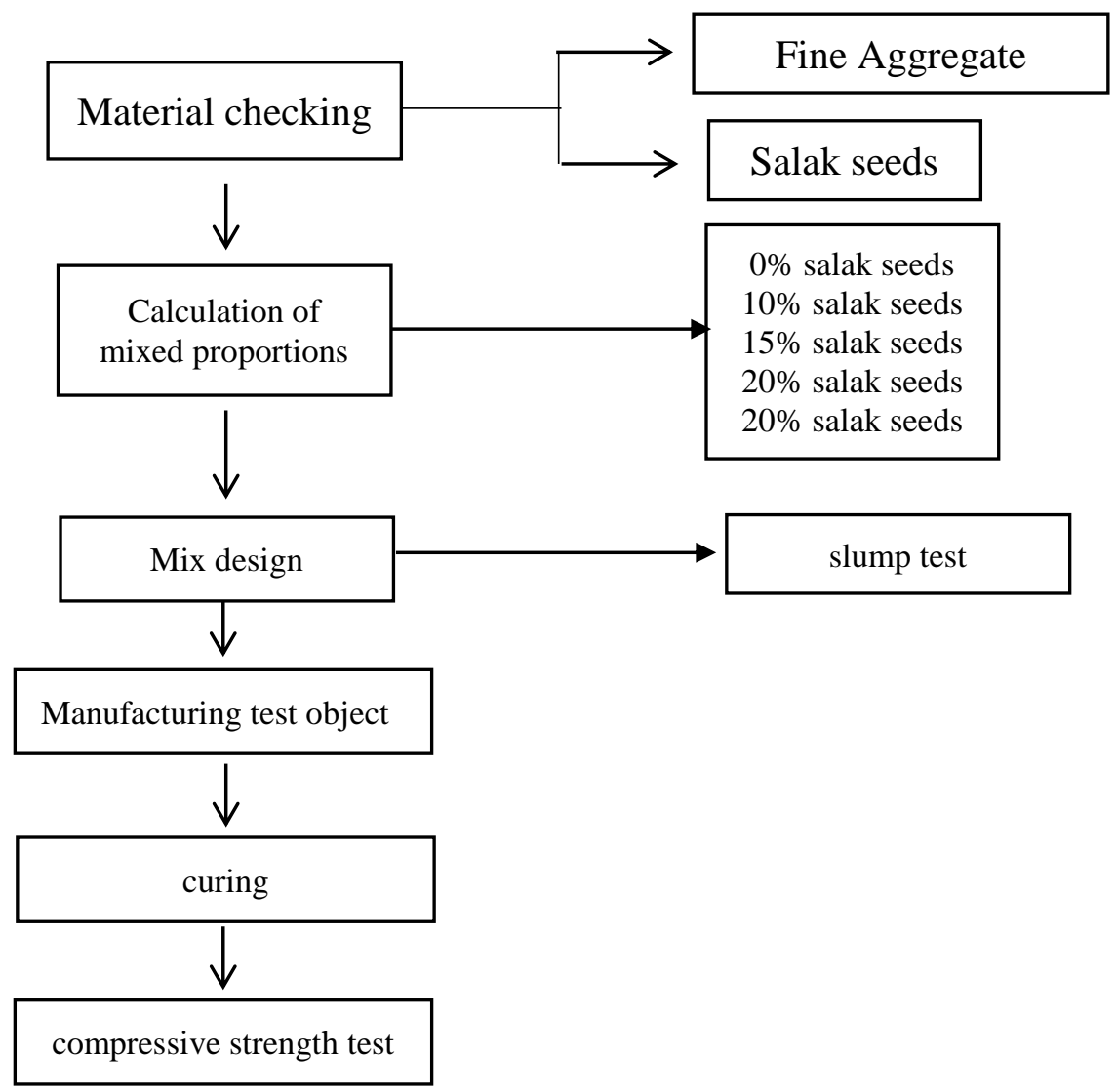

Figure 2. The stage of research

\section{RESULTS}

\section{a. Aggregate Testing}

The results of the examination of aggregate characteristics are considered in determining the design of the concrete

Table 3. Fine Aggregate Inspection Result

\begin{tabular}{|l|l|l|l|l|}
\hline No & Test Types & Results & Terms & Notes \\
\hline 1 & Water contents & $2,92 \%$ & $0,5-5 \%$ & Fulfill \\
2 & Sludge levels & $3,95 \%$ & Max 5\% & Fulfill \\
3 & Specific gravity & 3,10 & $1,6-3,3$ & Fulfill \\
4 & Asobsi & $1,63 \%$ & $0,2-2 \%$ & Fulfill \\
5 & Weight off Volume & $1,44 \mathrm{~kg} / \mathrm{liter}$ & $1,4-1,9 \mathrm{~kg} / \mathrm{liter}$ & Fulfill \\
6 & Solid Volume weight & $1,4 \mathrm{~kg} / \mathrm{liter}$ & $1,4-1,9 \mathrm{~kg} / \mathrm{liter}$ & Fulfill \\
7 & Organic Contents & No. 2 & < No. 3 & Fulfill \\
8 & Gradation & & Zona II & \\
& & & & \\
\hline
\end{tabular}

The results of the examination of the characteristics of coarse aggregate and fine aggregate are presented in the table Table 4. Coarse aggregate inspection result

\begin{tabular}{|l|l|l|l|l|}
\hline No. & Test Types & Results & Terms & Notes \\
\hline 1 & Water contents & $1,63 \%$ & $0,5-5 \%$ & Fulfill \\
2 & Sludge levels & $0,87 \%$ & Max 5\% & Fulfill \\
3 & Specific Gravity & 2,05 & $1,6-3,3$ & Fulfill \\
4 & Asobsi & $1,83 \%$ & $0,2-2 \%$ & Fulfill \\
5 & Weight off volume & $1,63 \mathrm{~kg} /$ liter & $1,4-1,9 \mathrm{~kg} /$ liter & Fulfill \\
6 & Solid volume weight & $1,69 \mathrm{~kg} /$ liter & $1,4-1,9 \mathrm{~kg} /$ liter & Fulfill \\
7 & Gradation & & Zona II & Fulfill \\
\hline
\end{tabular}


Table 5 shows the characteristics of salak seeds for further comparison with the characteristics of natural coarse aggregate.

Table 5. Characteristic of Salak Seeds

\begin{tabular}{|l|l|l|}
\hline No. & \multicolumn{1}{|c|}{ Test Types } & \multicolumn{1}{c|}{ Results } \\
\hline 1 & Water contents & $7,88 \%$ \\
2 & Specific gravity & 1,77 \\
3 & Absorbsi & $1,90 \%$ \\
4 & Weight off volume & $0,15 \mathrm{~kg} / \mathrm{liter}$ \\
5 & Solid volume weight & $0,18 \mathrm{~kg} / \mathrm{liter}$ \\
\hline
\end{tabular}

The results of the examination of the salak seeds characteristics shows a very high water content up to twice that of natural aggregates. Furthermore, the solid volume weight and loose volume weight of organic matter are highly low compared to natural coarse aggregate. The specific gravity of salak seeds shows a value between $1.6-3.3$ or meets the requirements of coarse aggregate.

\section{b. Concrete Mix design}

Results of design calculations mixture by DOE method obtained compotition of weight of constituent $1 \mathrm{M} 3$ concrete for compressive strength of concrete is presented in the table 6.

Table 6. Mix Design of Concrete

\begin{tabular}{|l|l|l|}
\hline Material & Weight $(\mathrm{Kg})$ & Composition \\
\hline Water & 190 & W/c $=0,35$ \\
\hline Cement Portland & 542.86 & 1 \\
\hline Sand & 644.73 & 1.18 \\
\hline Crushed stone & 845.41 & 1.55 \\
\hline
\end{tabular}

The results of the mix design require that the coarse and fine aggregates are in the SSD state. Furthermore, the addition of salak seeds refers to the percentage of coarse aggregate and produces the weight of SALAK SEEDS for every cubic meter of concrete. (table 7)

Table 7. Comparison of Coarse Aggregate Weight

\begin{tabular}{|l|l|l|}
\hline Salak Seeds Percentage & $\begin{array}{l}\text { Coarse Aggregate } \\
\text { Weight }(\mathrm{Kg})\end{array}$ & $\begin{array}{l}\text { SALAK } \\
\text { Weight }(\mathrm{Kg})\end{array}$ \\
\hline 0 & 845.41 & 0 \\
\hline 5 & 803.14 & 42.27 \\
\hline 10 & 760.87 & 84.54 \\
\hline 15 & 718.60 & 63.41 \\
\hline 20 & 676.33 & 84.54 \\
\hline
\end{tabular}

\section{c. Mixed Workability Testing}

Concrete mixtures are made by mixing the forming materials within a period of 10 to 15 minutes. Mixing time that is too short can cause a non-uniform mix . While the mixing time is too long can cause the separation of the constituent grains of concrete.

The workability of the mixture is carried out by using a slump test which refers to SNI 1972-2008 .

Table 8. Slump Test Results

\begin{tabular}{|c|l|}
\hline Salak Seeds Percentage & Slump $(\mathrm{mm})$ \\
\hline 0 & 90 \\
\hline 5 & 90 \\
\hline 10 & 90 \\
\hline 15 & 85 \\
\hline 20 & 85 \\
\hline
\end{tabular}

The workability value of fresh concrete in the five types of mixtures shows relatively the same number. These results indicate that the addition of salak seeds does not affect the workability of the concrete

\section{d. Compressive Strength}

After making and maintaining the test object, then the compressive strength test of the test object is carried out. The compressive strength test of concrete was carried out on specimens aged 7, 14, 21 and 28 days as many as 20 samples for 
each variation of the mixture.

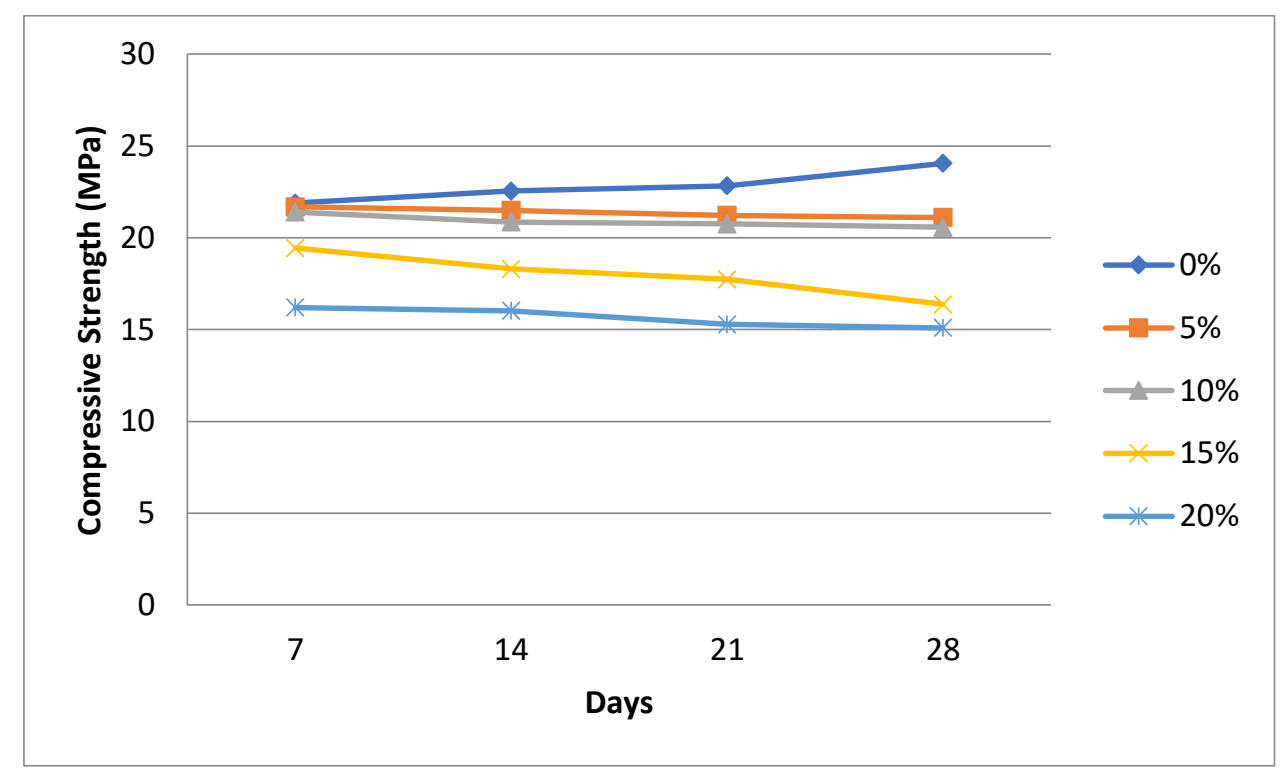

Fig 3. Graph of The Compressive Strength Of Concrete

Figure 3 describes the test results of concrete without salak seeds at the age of 28 days at 24.062 MPa. For the percentage of salak seeds $5 \%$, the 28 -day compressive strength value was 21.682 with a ratio of $90 \%$ compared to a mixture of $0 \%$ salak seeds. Mixed concrete with $10 \%$ of salak seeds produce compressive strength $21.401 \mathrm{MPa}$, or $88.9 \%$ of strong concrete without salak seeds. Replacement of $15 \%$ coarse aggregate with salak seeds causes a decrease in compressive strength of $20 \%$ and produces a strength of $19.439 \mathrm{MPa}$. Moreover with the addition of $20 \%$ salak seeds, the compressive strength of the female only reached 14,996 MPa. Thus, the addition of 5\% and $10 \%$ of salak seeds resulted in a concrete compressive strength that exceeded the design concrete compressive strength . While the percentages of $15 \%$ and $20 \%$ are not recommended because they produce a highly low compressive strength of concrete .

The achievement of the compressive strength of concrete is assessed as a strength ratio or percentage of strength at a certain age compared to the compressive strength of 28 days. A large ratio value at the initial age of the concrete indicates a faster achievement of the compressive strength of the concrete. The results of the calculation of the strength ratio are presented in Figure 4

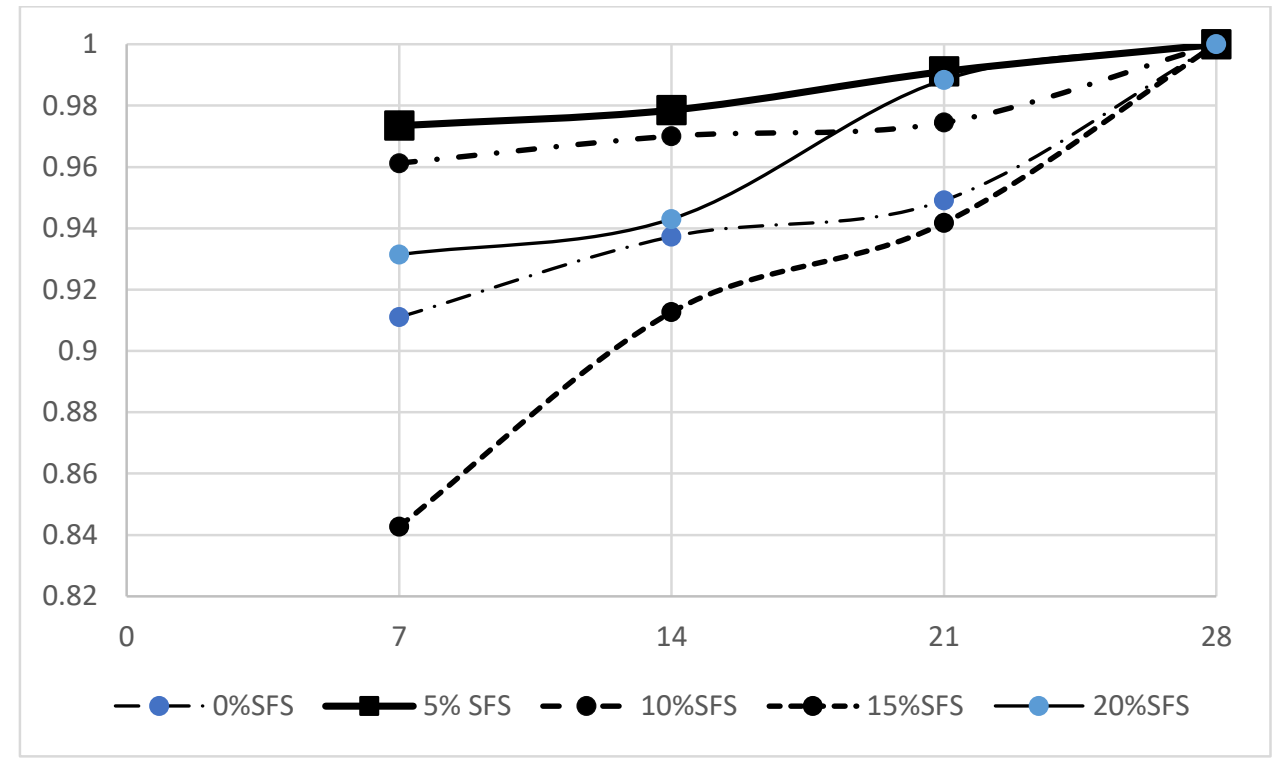

Fig 4. Strength Rasio in Several Variation of Concrete Mix

Concrete with $10 \%$ and $15 \%$ salak seeds showed a high strength ratio value (more than 0.95 ) at 7 days of age. This ratio increases with the increase in the generality of the concrete. While the percentage of $15 \%$ and $20 \%$ salak seeds, the ratio value is very low. Moreover at the age of 21 days the ratio of attainment of strength is less than $95 \%$. 
Based on the results of the analysis, the authors found that the addition of salak seeds with a percentage of less than $10 \%$ gave good results. The value of workability, compressive strength of concrete and the achievement of initial compressive strength are indicators of concrete quality with salak seeds.

\section{DISCUSSION}

The use of waste as a substitute for coarse aggregate in the manufacture of concrete has been widely implemented throughout the world. [6] described the use of crushed granite as coarse aggregate. The use of this waste material gives a good compressive strength of concrete with a composition of less than $20 \%$ of natural aggregate. While other researchers [11] described the results of his study using clay bricks as coarse aggregate. The percentage of $25 \%$ clay brick produces a compressive strength that exceeds $25 \mathrm{MPa}$ with a specific gravity of $1647 \mathrm{~kg} / \mathrm{m} 3$. [12] described that agricultural waste allows its use as concrete aggregate. Coconuts shells can be used as aggregate in the production of lightweight concrete. The use of these materials contributes to reducing the exploitation of natural materials.

The use of salak seeds in the manufacture of concrete has never been done before. Its hard nature and size resembling coarse aggregate allow it to be used as a concrete aggregate. However, its use is only limited in certain proportions because of the uniform grain size. This will affect the weak bonding capacity between the cement matrix and the aggregate.

\section{CONCLUSION}

From the results of the study, it can be concluded that salak seeds are suitable to be used as a partial substitute for coarse aggregate in concrete mixtures. The percentage content of salak seeds in the mixture should not exceed $10 \%$ because the strength of salak seeds cannot exceed the strength of natural aggregates. Although the strength of concrete using natural aggregates is stronger than using a mixture of salak seeds, but here we can utilize one of the organic wastes, namely seeds. salak as an ingredient in concrete mixtures with a percentage of $10 \%$ of the total aggregate used in concrete mixtures to reduce organic waste

\section{REFERENCES}

[1] M. Bendixen et al., "Promises and perils of sand exploitation in Greenland," Nat. Sustain., vol. 2, no. 2, pp. 98104, 2019.

[2] F. Debieb and S. Kenai, "The use of coarse and fine crushed bricks as aggregate in concrete," Constr. Build. Mater., vol. 22, no. 5, pp. 886-893, 2008.

[3] A. Akhtar and A. K. Sarmah, "Strength improvement of recycled aggregate concrete through silicon rich char derived from organic waste," J. Clean. Prod., vol. 196, pp. 411-423, 2018.

[4] E.-I. Yang, S.-T. Yi, and Y.-M. Leem, "Effect of oyster shell substituted for fine aggregate on concrete characteristics: Part I. Fundamental properties," Cem. Concr. Res., vol. 35, no. 11, pp. 2175-2182, 2005.

[5] B. Peceño, C. Arenas, B. Alonso-Fariñas, and C. Leiva, "Substitution of coarse aggregates with mollusk-shell waste in acoustic-absorbing concrete," J. Mater. Civ. Eng., vol. 31, no. 6, p. 4019077, 2019.

[6] N. K. Sharma, P. Kumar, S. Kumar, B. S. Thomas, and R. C. Gupta, "Properties of concrete containing polished granite waste as partial substitution of coarse aggregate," Constr. Build. Mater., vol. 151, pp. 158-163, 2017.

[7] I. O. Ogunwemimo, L. O. Salami, and A. O. Familusi, "Evaluation Of Palm Kernel Shell As A Partial Replacement For Coarse Aggregate In Concrete," J. New Trends Civ. Eng., vol. 1, no. 2, pp. 1-4, 2019.

[8] S. Luhar, T.-W. Cheng, and I. Luhar, "Incorporation of natural waste from agricultural and aquacultural farming as supplementary materials with green concrete: A review," Compos. Part B Eng., vol. 175, p. 107076, 2019.

[9] M. Abhilash, S. Jhanjhari, P. Parthiban, and J. Karthikeyan, "Axial behaviour of semi-lightweight aggregate concrete-filled steel tube columns-A DOE approach,” J. Constr. Steel Res., vol. 162, p. 105614, 2019.

[10] M. V Chitawadagi, M. C. Narasimhan, and S. M. Kulkarni, "Axial capacity of rectangular concrete-filled steel tube columns-DOE approach,” Constr. Build. Mater., vol. 24, no. 4, pp. 585-595, 2010.

[11] N. M. Ibrahim, S. Salehuddin, R. C. Amat, N. L. Rahim, and T. N. T. Izhar, "Performance of lightweight foamed concrete with waste clay brick as coarse aggregate," Apcbee Procedia, vol. 5, pp. 497-501, 2013.

[12] K. Gunasekaran, R. Annadurai, and P. S. Kumar, "Long term study on compressive and bond strength of coconut shell aggregate concrete," Constr. Build. Mater., vol. 28, no. 1, pp. 208-215, 2012. 